\title{
Nomınal and Verbal Predıcate Use in Schızophrenıa
}

\section{Употребление номинальных и вербальных предикатов в речи больных шизофренией}

\author{
Ayşegül Özcan Vural \\ Ph.D. in General Linguistics, \\ Lecturer
}

\author{
Айшегюль Озджан Вурал \\ кандидат филологических наук, \\ преподователь
}

E-mail: aysegul.ozcan@deu.edu.tr https://orcid.org/0000-0002-8711-8399

\section{Gülmira Kuruoğlu \\ Ph.D. in Linguistics, Professor}

\section{Гюльмира Куруоглу}

кандидат филологических наук, профессор

E-mail: gulmira.kuruoğlu@deu.edu.tr

https://orcid.org/0000-0002-4172-0253

Dokuz Eylul University, Faculty of

Letters, Department of Linguistics

$\bowtie$ Buca-Izmir, Turkey, 35390

Original manuscript received September 24, 2019

Revised manuscript accepted February 18, 2020

\begin{abstract}
Objective. Schizophrenia's first characteristics invokes the notion of disordered thought and language. Accordingly one of several diagnostic characteristics of schizophrenia is an impairment of verbal communication. To determine the detailed nature of language impairments taking into consideration these problems the aim of the present study was to analyze nominal and verbal predicate use produced by schizophrenic patients and control group during their speech as both predicates require different processings. Materials \& Methods. Fifty patients with schizophrenia diagnosed according to DSM-IV criteria were included into the study and compared to fifty healthy subjects matched for age, sex and education level with the patients participated in the study.
\end{abstract}


The subjects' speech was evaluated by using picture description test, picture story telling test, subject-based narration test and free verbal narration test. The data consisted of 8-10 minute recorded interviews. The recordings were transcribed based on Du Bois' Discourse Transcription Symbols and analyzed statistically and linguistically. Results. The results showed that the number of nominal and verbal predicates used by the patients with schizophrenia differed from the control group. Schizophrenia patients preferred nominal predicates more than control group in all tests. However, control group used significantly more verbal predicates in all tests.

Conclusions. In this study it was hypothesized that language used by the patients with schizophrenia plays a central role in the this disease than commonly supposed and the phenomena of schizophrenic language can be regarded as reflections of a more basic disturbance of thought. At the end of the study based on this hypothesis patients were concluded to have simplified speech in addition to the disorganized speech defined in the field. The reason for this simplification is thought to be because of the predicate processing in the brain. The complement of a verb is always a noun phrase, which can be simple or complex, the patients tended to use nominal predicates more as it did not require any constituents and thus they simlified their speech because of their language and thought disorders.

Key words: schizophrenia, sentence, predicate, nominal, verbal, language disorder, thought disorder.

\section{Introduction}

Schizophrenia is a neuropsychiatric disorder with a variety of symptoms and cognitive impairments. This chronic psychiatric disorder with a heterogeneous genetic and neurobiological influences early brain development, and is expressed as a combination of psychotic symptoms such as hallucinations, delusions and disorganization and motivational and cognitive dysfunctions. According to the World Health Organization (WHO) the term schizophrenia was introduced into at the beginning of this century by the Swiss psychiatrist Bleuler. According to Bleuler schizophrenia refers to a major mental disorder, or group of disorders, whose causes are still largely unknown and which involves a complex set of disturbances of thinking, perception and social behaviour.

Schizophrenia is a chronic psychiatric disorder with a heterogeneous genetic and neurobiological background that influences early brain development, and is expressed as a combination of psychotic symptoms - such as hallucinations, delusions and disorganization - and motivational and cognitive dysfunctions. 
Symptoms of schizophrenia can be divided into 'positive', 'negative' and 'cognitive' categories. Positive symptoms are behaviours and thoughts that are not normally present, such as recurrent psychosis, which is the 'loss of contact with reality' consisting of delusions, hallucinations and disorganized speech and behaviour. The negative symptoms include social withdrawal, affective flattening, the inability to feel pleasure and diminished initiative and energy. Finally, cognitive symptoms are expressed as a broad set of cognitive dysfunctions (Kahn et al., 2015).

In schizophrenia, there have been also several attempts to describe thought and language output and these have centered to describe the speech produced by patients and to examine language output in terms of lexical, syntactic and discourse structure. Analyses about syntax in schizophrenia patients' speech suggested that it was more grammatically deviant and less syntactically complex than that of controls (Hoffman \& Sledge, 1988; Fraser et al., 1986b). Kircher et al. (2005) also examined syntax production in people with schizophrenia and showed the neural correlates between healthy and control subjects. In their study, it was found that the syntactically complex sentence count activity within the posterior right middle temporal cortex and superior frontal cortex correlated with produced in the healthy controls but not the schizophrenia patients. The failure to recruit these regions was interpreted as contributing to patients' syntactically simpler speech. Within this context, disorganized thinking is thought to lead to a crash or a sudden stop in thought process, randomly in spoken words, in total coherence and then cause disjointed thoughts. These thought and language deviations result in simplified speech and one of the deviations done by the patients is the predicate use. Namely, if the predicate is a verb as it requires a complex process, patients with schizophrenia will tend to use nominal predicates more.

The predicate expresses an event, a process or a state in which the subject is involved:

(a) 'My sister will complete the project within a week.'

(b) 'This child is ill.'

The predicate of a simple sentence, or of the main clause in a complex sentence, is described as finite. According to the type of predicate they have, sentences are divided into two main groups, verbal sentences and nominal sentences. Verbal sentences are sentences whose 
predicates are finite (c) and nominal sentences are sentences whose predicate either does not contain an overt verb at all or whose verb is one of the forms of the copula ('be', 'become', 'exist').

(c) 'I can't stay at home today.'

(d) 'She is a teacher.'

Nominal sentences are of two kinds: linking and existential. Whereas linking sentences present, or assume knowledge of, a subject and relate some attribute or identification to it, existential sentences merely assert the existence or presence of a subject. The statement is usually made in relation to either (i) a location intime or space, or (ii) a possessor). It is known that if the sentence is verbal, it is more complex than nominal sentence. In verbal sentence a complement is needed and a constituent completes the meaning of the verb, and stands in a particular structural relationship to it. The complement of a verb is always a noun phrase, which can be simple or complex and it represents the person(s) or thing(s) affected by the action of the verb (Göksel \& Kerslake, 2005).

The present study in this sense investigated whether the predicate use was simplified in schzoprenia patients' speech as the patients are known to have a tendency to speak in short, to use simplified sentences with omission of some grammatical features such as simple sentence instead of complex sentences.

\section{Methods}

\section{Subjects}

Prior to commencing study, permission was approved by the Medical School of Dokuz Eylül University, Interference-Free Ethics Committee on 06.06.2013 with the decision numbered 2013/21-18 numbered 1036-GOA. Fifty patients diagnosed with schizophrenia according to DSM-IV in Dokuz Eylul University Mental Health and Illness Department and 50 healthy participants matched in terms of their age, gender and educational level participated in the study. The number of subjects in the study was determined using power analysis. This analysis was based on the number of patients with schizophrenia living in Turkey and Izmir. At the average of $\alpha=0.05$, the frequency of schizophrenia in İzmir was $0.85 \%$ and in this study 50 patients with 0.05 error margin were included. 
The control group included in the study included the individuals residing in İzmir province. The control group did not have a neurological or psychiatric discomfort story. It was defined as the criteria for participation in the study for healthy individuals who did not have a progressive central nervous system disease (Alzheimer's, Parkinsonism, etc.), psychiatric disorder, sensory problems (visual problems, neglect, hearing problems, etc.), a history of a stroke or brain disorder (tumor, head trauma, etc.), substance abuse, language, speech or learning problem story, drug use known to affect cognition. Besides, all participants mother tongue was Turkish and volunteering for participation in the research was defined as the criteria for participation for healthy individuals. The demographic information on the subjects is as shown in Table 1.

Table 1. Demographic characteristics of schizophrenia patients and control group

\begin{tabular}{llll}
\hline & $\begin{array}{l}\text { Schizophrenia } \\
(\mathbf{n}=\mathbf{5 0 )}\end{array}$ & $\begin{array}{l}\text { Control Group } \\
(\mathbf{n}=\mathbf{5 0 )}\end{array}$ & t-test \\
\hline Age & 41.98 & 41 & $\mathrm{p}=0.60$ \\
Gender & & & $\mathrm{p}=1.0$ \\
Female & 17 & 17 & $\mathrm{p}=1.0$ \\
Male & 33 & 33 & $\mathrm{p}=0.94$ \\
Education Year & 10.9 & 11.21 & \\
\hline
\end{tabular}

As shown in Table 1, there was no significant difference in terms of age, gender, education level between patients and healthy individuals. 34 female (17 schizophrenia - 17 control groups) and 66 male subjects (33 schizophrenia - 33 control) participated in the study. 4 subjects in the schizophrenia group were primary school graduate, 5 subjects were secondary school graduate, 9 subjects were high-school graduate and 7 subjects were university graduate. Similarly, 2 subjects in control group were primary school graduate, 1 subject was secondary school graduate, 15 subjects were high-school graduate and 7 subjects were university graduate.

\section{Data Collection}

The data collection process was carried out on Wednesdays between 2012 and 2014 at the Policlinic of Schizophrenia and Psychotic Disorders of the Department of Mental Health and Illness of the Medical Faculty of Dokuz Eylul University. Before the commencement of the 
application of the tasks, a pilot study was carried out between 20112012 to determine whether the patients were experiencing problems in interpreting the pictures used or the pictures correspondent with Turkish culture. As a result of this application, both the schizophrenia group and the control group did not have any problems when interpreting the two picture tests used in the study. The researcher filled in the forms containing the demographic information by asking the questions to the participant verbally (Participant Information Form) before the application. The information on these forms provided information on age, gender, educational variables. In addition, participants were obtained permission that they voluntarily participated in the study and that they accepted the voice recording. Each participant was instructed by the researcher and the participant's questions about the application were answered.

During the application, each patient was interviewed individually in the psychologist's office. The room where the tasks were performed was quiet so as not to distract the patients. After the data on schizophrenic patients were collected, all tests were applied to the control group who were matched with age, gender and education level with the patients in the same order. Participants' speech in the tests was recorded via a voice recorder. The data was collected by recording with the Philips LFH0615 audio recorder and the recordings were transcribed using the symbols created by Du Bois (1991).

\section{Process}

In order to determine the average predicate use of schizophrenia patients who applied to the Policlinic of Schizophrenia and Psychotic Disorders Policlinic of Dokuz Eylül University Medical Faculty, Department of Mental Health and Diseases and the control group in different narrative types, four tests were used which were narrative picture task, story picture sequencing task, semi-structured speech task and free speech task, and each subject was interviewed for about 15 minutes.

The first two tasks used in the study were picture tasks. The first picture was «Picnic» picture aimed at describing and the other picture was «Hat» picture consisting of 12 pictures to create a story. The first task was a picture of a picnic on the lake taken from Western Aphasia test. The «Hat» picture was taken from the book «Vosstanovleniye Reçu u Bolnix s Afaziey» (Aphasic Speech Rehabilitation Book) and it was 
related to the story of a man wearing a hat. The subjects were asked to tell the story by thinking about the connections among the pictures. Both pictures are thought to be easy to describe and each takes an average of 2 minutes. During the process all subjects talked about each story and the pictures were shown to the subjects in the same order. In order to prevent performance decrease that might be caused by shortterm memory problems (Wicksell et al., 2004; Liddle et al., 2002), subjects could look at pictures until they had completed their tasks.

After the picture tasks, two verbal tasks without visual contents were applied to the subjects. Whereas the first verbal task guided them with a question, the second one was related to a free speech and the subjects talked whatever they wanted. In the first verbal task, subjects were asked what they thought about the situation of their country in recent years while in the second verbal task without any guidance, they were tested on whether they could talk about anything that they wanted. Thereafter, the resulting responses were evaluated.

Each task was recorded and the resulting audio recordings were transcribed into transcriptions based on symbols indicated by $\mathrm{Du}$ Bois (1991). The obtained data were analyzed according to the aims of the study and statistical analysis and linguistic evaluations were made.

\section{Statistical Analysis}

The data collected according to the method of the study were evaluated in terms of the aims of the study and analyzed statistically. In the study, which was analyzed in terms of nominal and verbal predicate use produced by schizophrenic patients during their speech, firstly the chi-square test was used in order to reveal the relation between the predicate use and the schizoprenia. Secondly the median test was used to find out the difference between the nominal and verbal predicates used by the schizophrenia and the control group The findings obtained after statistical analysis were interpreted linguistically and discussed in the light of relevant literature.

\section{Results}

In this study it was aimed to find out whether predicate use has a relationship with schizophrenia and the results comfirmed the the hypothesis. The results are as shown in Table 2. 
Вживання номінальних $і$ вербальних предикатів у мові хворих...

Table 2. Chi-square and Median Test Findings on Nominal and Verbal Predicate Use of Schizoprenia and Control Group

\begin{tabular}{lllllllll}
\hline & Predicate & $\begin{array}{l}\text { Sentence } \\
\text { Count } \\
\text {-Sch }\end{array}$ & $\begin{array}{l}\text { f\%) } \\
\text { (\%) }\end{array}$ & $\begin{array}{l}\text { Sentence f } \\
\text { Count- } \\
\text { Control }\end{array}$ & $\begin{array}{l}\text { f } \\
\text { (\%) }\end{array}$ & $\begin{array}{l}\text { Median } \\
(\%)\end{array}$ & $\begin{array}{l}\text { chi- } \\
\text { p value }\end{array}$ & $\begin{array}{l}\text { square } \\
\text { p value }\end{array}$ \\
\hline Narrative & Nominal & 281 & 56.0 & 221 & 44.0 & 100 & 0.038 & \multirow{2}{*}{0.002} \\
Picture Task & Verbal & 298 & 45.7 & 354 & 54.3 & 100 & 0.009 & \\
Story Picture & Nominal & 138 & 55.7 & 92 & 44.3 & 100 & 0.013 & \multirow{2}{*}{0.001} \\
Sequencing Task & Verbal & 759 & 46.7 & 867 & 53.3 & 100 & & \\
Semi-structured & Nominal & 139 & 55.4 & 107 & 44.6 & 100 & 0.78 & \multirow{2}{*}{0.008} \\
Speech Task & Verbal & 326 & 47.8 & 351 & 52.2 & 100 & 0.048 & \\
Free Speech & Nominal & 143 & 57.5 & 108 & 42.5 & 100 & 0.028 & \multirow{2}{*}{0.045} \\
Task & Verbal & 374 & 42.9 & 495 & 57.1 & 100 & 0.021 & \\
\hline
\end{tabular}

As shown in Table 2, in Narrative Picture Task there was a significant relationship between schizophrenia and the predicate use $(p<0.005)$. It was revealed that schizophrenia affected the predicate use in this task. According to the results obtained from the median test, there was a significant difference between the schizophrenic patients and the control group in terms verbal predicate use $(p<0.005)$. According to the results, schizophrenia patients used less verbal predicate than control groups.

In Story Picture Sequencing Task there was also a significant correlation between schizophrenia and the predicate use $(\mathrm{p}<0.005)$. Namely, schizophrenia disease had an effect on predicates. According to the median test results, a significant difference was also found between the schizophrenia patients and control group in terms of the verbal predicate use $(\mathrm{p}<0.005)$. Whereas schizophrenia patients used less verbal predicates, nominal predicate use of both groups was not significantly correlated $(\mathrm{p}>0.005)$.

In Semi-structured Speech Task, significant correlation was again found between the schizophrenia and the predicates $(p<0.005)$. Median test was again consistent with chi-square test and it revealed that there was significant difference between the schizophrenia patients and the control group in terms of verbal predicate use $(p<0.005)$. According to the results verbal predicates used by schizophrenia patients were significantly less than control group.

Finally, in Free Speech Task, a significant correlation was found between the disease and the predicate use $(p<0.005)$. Schizophrenia 
affected the sentence predicate use in this task and according to the results of the median test, there was again a significant difference between the schizophrenia patients and the control group in nominal and verbal predicate use $(p<0.005)$. The results revealed that schizophrenia patients used more nominal and less verbal sentences than control group. The graphs showing the results are as follows:

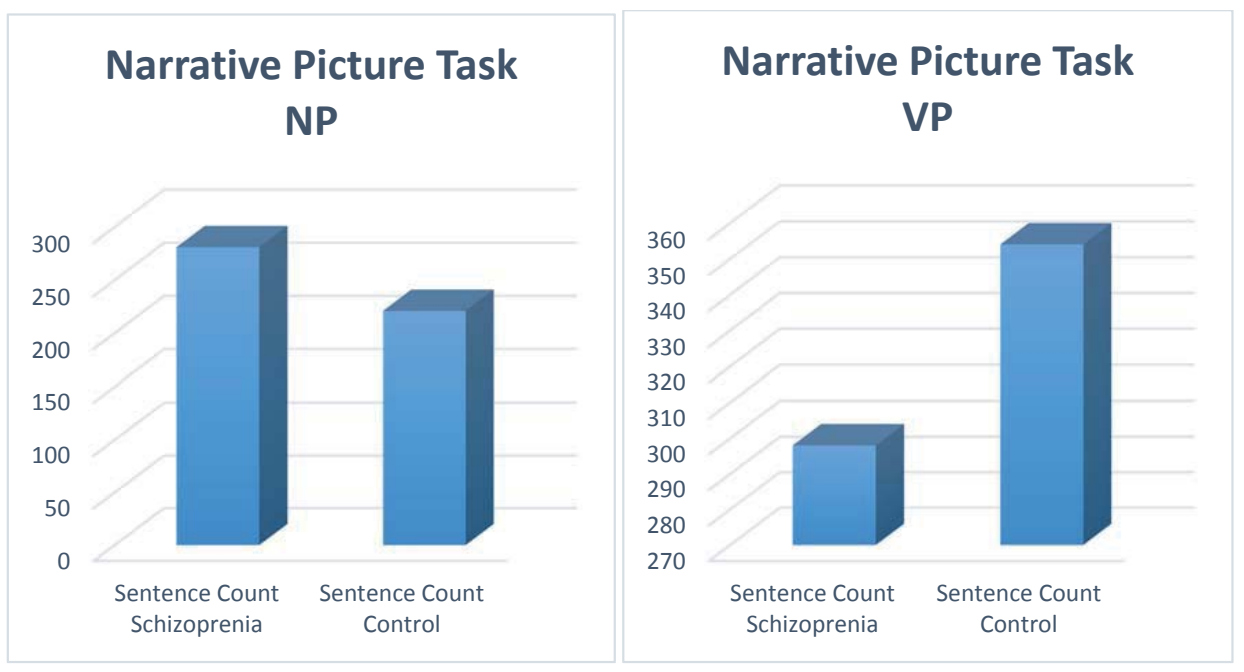

Graph 1. Nominal and verbal predication in narrative picture task

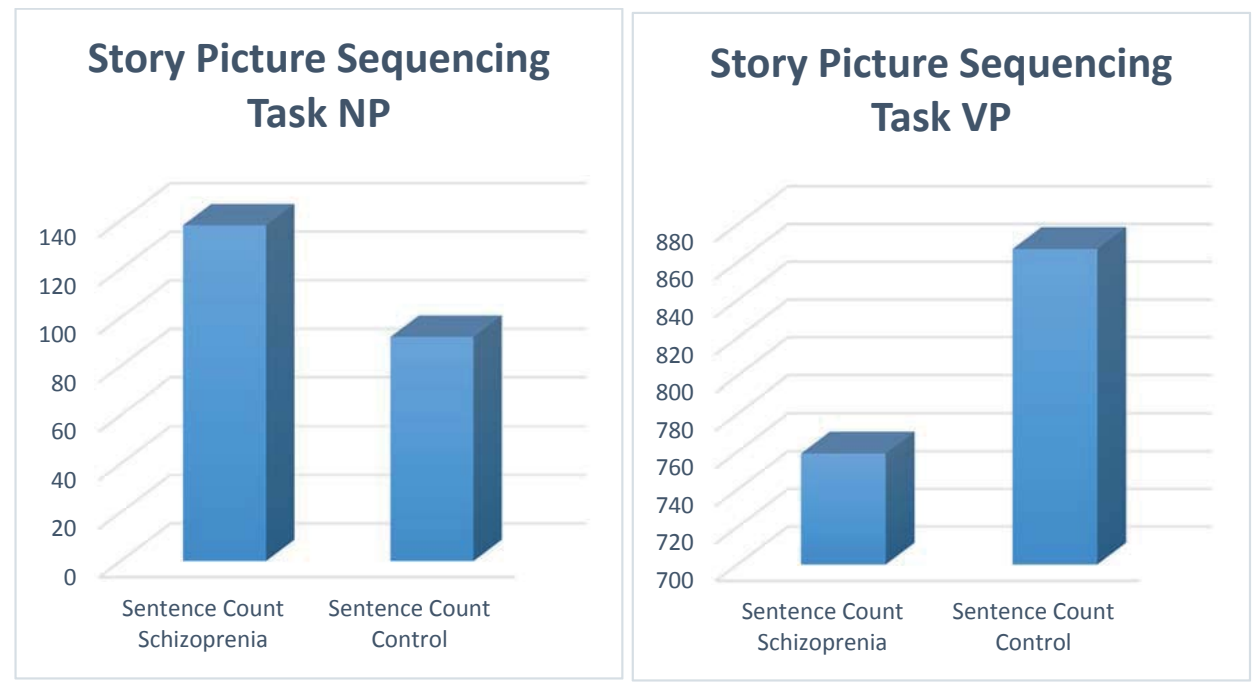

Graph 2. Nominal and verbal predication in story picture sequencing task 

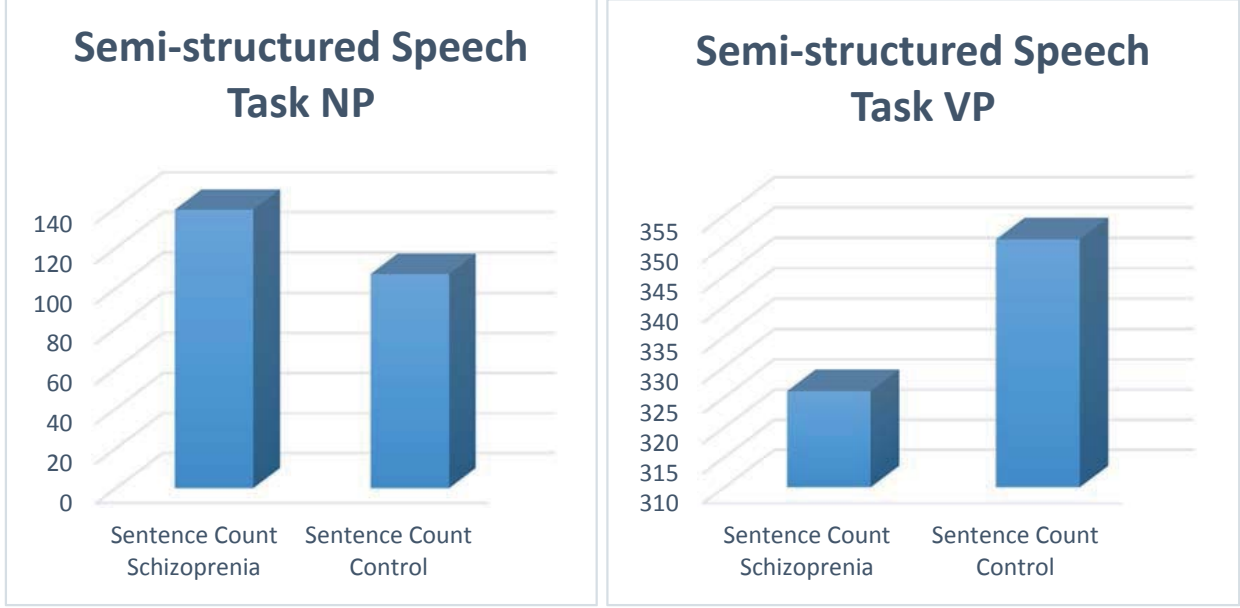

Graph 3. Nominal and verbal predication in semi-structured speech task

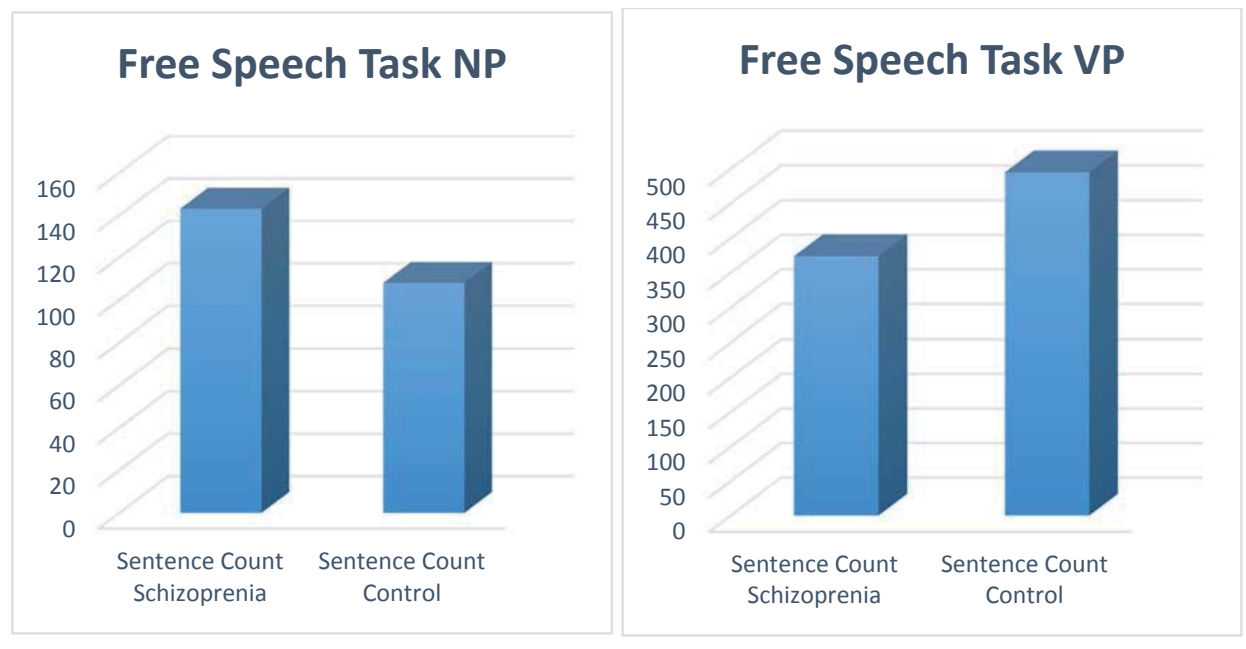

Graph 4. Nominal and verbal predication in free speech task

As shown in the graphs above, schizophrenia patients' nominal predicate use in all tests were higher than the control group.

\section{Discussion and Conclusion}

Language is one of the primary means by which social environment is engaged with. Phenomena such as a hearing impediment, 
a congenital defect, brain damage, or mental illness can compromise the fine-tuned system that produces and comprehends fluent language. Of these, one particular mental illness, schizophrenia is a complex, chronic mental health disorder characterized by an array of symptoms, including delusions, hallucinations, disorganized speech or behavior, and impaired cognitive ability (Patel et al., 2014).

Schizophrenia can produce global, and heterogeneous deficits in language. These deficits have been analyzed qualitatively by many researchers (Andreasen, 1979). In the formal analysis of language in schizophrenia, we can subdivide differences into a few core features: lexicon, phonology, morphology, syntax, semantics and pragmatics (Covington et al., 2005; McGregor, 2015). Several aspects of language in schizophrenia seem to draw from each of these categories simultaneously, with certain language features bestriding two or more different areas. In this sense it is thought that shizophrenia patients' brain organization for language plays a more central role in this disease than commonly supposed. Against the standard view, that schizophrenia is a disturbance of thought or selfhood, it is argued that the origins of the relevant forms of thought and selfhood at least partially depend on language and can be investigated in many levels as stated above (Hinzen \& Rosello, 2015).

In the literature there are many researches about this. Condray et al. (1994) for instance examined schizoprenic language in semantics and syntax level and studied comprehension of complex and simple sentences. As a result, decreased comprehension associated with decreased working memory load was found. Landre \& Taylor (1995) examined Porch index of communicative ability and other factors and patients with schizoprenia exhibited more intrusion from the priming. Aloia et al. (1996) studied on spontaneously cluster exemplars from a specific category during a fluency task and patients showed less stable dimensional organization of exemplars into subordinate clusters than controls, suggesting disorganized semantic networks.

Besides, there are many studies on schizophrenic deviation in syntax level. Joyce et al. (1996) found inefficient access to semantic stores together with the deviationsin syntax.

Özcan et al. (2018) showed that patients with schizoprenia tend to form shorter sentences compared to the control group and the findings were similar to the other studies in the literature. Heim \& Cohen (1981) 
in the same way examined the patients with schizophrenia and they showed a steeper slope of utterance length across levels of difficulty. In the schizophrenic group, the degree of general psychopathology as well as paranoid and anergic tendencies correlated negatively with communication accuracy, utterance length, and the number of descriptions referring to both colors of an item in the simultaneous presentation condition. Özcan et. al. (2017) also found that in addition to diminished speech amount in terms of complex sentence structure patients with schizophrenia displayed abnormalities of language. Results showed that patients and controls differed in their production of a complex sentence, with patients exhibiting a significant reduction in their production, compared to the speech of the control group. In qualitative syntactic coding, it was also demonstrated that patients with schizophrenia exhibitted an overall simplified, but correct, syntactical structure to their language when compared to controls (Fraser, King, Thomas \& Kendell, 1986a).

Within this context in this study nominal and verbal predicate use produced by schizophrenic patients during their speech was analyzed as both predicates require different processing in terms of simplification and the findings of the study revealed that schizophrenia patients and control group showed differences in predicate use.

In all tests, nominal predicates used by schizophrenia patients were found more than the control group. By contrast, the control group preferred verbal predicates in their speech. The findings of this study showed that schizophrenia patients simplified sentences while communicating. As verbal predicates are structures that require more processing than nominal predicates. In other words, verbal predicates contain sub-categories framed around verbal predicates and the relationships between these sub-clauses. However, nominal predicates do not have such complex relationship. Therefore, it is thought that schizophrenia patients use structures that require less processing in their speech. Another reason why schizophrenia patients use nominal predicates is thought to be due to the intent of the action and the desire to cover some units implicitly; because the nominal predicates allow the implicit roles of the participants in an event (Potter, 1996: 182). At this point, it may be thought that the patients choose the way of disguising information when describing the events. 


\section{References}

Aloia, M.S., Gourovitch, M.L., Weinberger, D.R., \& Goldberg, T.E. (1996). An investigation of semantic space in patients with schizophrenia. Journal of International Neuropsychology Society, 2, 267-273. https://doi.org/10.1017/ S1355617700001272

Andreasen, N.C. (1979). Thought, language, and communication disorders: I. Clinical assessment, definition of terms, and evaluation of their reliability. Archives of General Psychiatry, 36 (12), 1315-1321. https://doi.org/10.1001/ archpsyc.1979.01780120045006

Condray, R., Steinhauer, S.R., van Kammen, D.P., \& Kasparek, A. (1996). Working memory capacity predicts language comprehension in schizophrenic patients. Schizophrenia Research, 20, 1-13. https://doi.org/10.1016/0920-9964(95)00061-5

Covington, M.A., He, C., Brown, C., Naçi, L., McClain, J.T., Fjordbak, B.S., Semple, J., \& Brown, J. (2005). Schizophrenia and the structure of language: the linguist's view. Schizophrenia Research, 77 (1), 85-98. https://doi.org/10.1016/j. schres.2005.01.016

Du Bois, J.W. (1991). Transcription design principles for spoken discourse research. Pragmatics. Quarterly Publication of the International Pragmatics Association (IPrA), 1 (1), 71-106. https://doi.org/10.1075/prag.1.1.04boi

Fraser, W.I., King, K.M., Thomas, P., \& Kendell, R.E. (1986a). The diagnosis of schizophrenia by language analysis. British Journal of Psychiatry, 148, 275-278. https://doi.org/10.1192/bjp.148.3.275

Fraser, B.J., Treagust, D.F., \& Dennis, N.C. (1986b). Development of an instrument for assessing classroom psychosocial environment at universities and colleges. Studies in Higher Education, 11, 43-54. https://doi.org/10.1080/0307507861233 1378451

Göksel, A., \& Kerslake, C. (2005). Turkish: A comprehensive grammar. London: Routledge. https://doi.org/10.4324/9780203340769

Heim, G., \& Cohen, R. (1981). Referent communication of chronic schizophrenics and chronic alcoholics under simultaneous and successive task presentation. Archiv für Psychiatrie und Nervenkrankheiten, 230 (4), 325-337.

Hinzen, W., \& Rosselló, J. (2015). The linguistics of schizophrenia: thought disturbance as language pathology across positive symptoms. Frontiers in psychology, 6, 971. https://doi.org/10.3389/fpsyg.2015.00971

Hoffman, R.E., \& Sledge, W. (1988). An analysis of grammatical deviance occurring in spontaneous schizophrenic speech. Journal of Neurolinguistics, 3 (1), 89-101. https://doi.org/10.1016/0911-6044(88)90008-5

Joyce, E.M., Collinson, S.L., \& Crichton, P. (1996). Verbal fluency in schizophrenia: Relationship with executive function, semantic memory and clinical alogia. Psychological Medicine, 26, 39-49. https://doi.org/10.1017/S0033291700033705

Kahn, R.S., Sommer, I.E., Murray, R.M., Meyer-Lindenberg, A., Weinberger, D., Cannon, T.D., O’Donovan, M., Correll, C.U., Kane, J.M., Os, V.J., \& Insel, T.R. (2015). Schizophrenia. Nature Reviews Disease Primers, 1, 15067. https://doi. org/10.1038/nrdp.2015.67

Kircher, T.T., Oh, T.M., Brammer, M.J., \& McGuire, P.K. (2005). Neural correlates of syntax production in schizophrenia. British Journal of Psychiatry, 186, 209-214. https://doi.org/10.1192/bjp.186.3.209 
Landre, N.A., \& Taylor, M.A. (1995). Formal thought disorder in schizophrenia: Linguistic, attentional, and intellectual correlates. Journal of Nervous and Mental Disease, 183, 673-680. https://doi.org/10.1097/00005053-199511000-00001

Liddle, P.F., Ngan, E.T.C., Caissie, L., Anderson, C.M., Bates, A.T., Quested, D.J., White, R. ve Weg, R. (2002). Thought and Language Index: an instrument for assesing thought and language in schizophrenia. The British Journal of Psychiatry, 181 (4), 326-330. https://doi.org/10.1192/bjp.181.4.326

McGregor, W.B. (2015). Linguistics: an introduction. Bloomsbury Publishing.

Özcan, A., \& Kuruoğlu G. (2018). Sentence length of Turkish patients with schizophrenia. International Journal of Psycho-Educational Sciences, 7(1), 68-73.

Özcan, A., Kuruoğlu, G., \& Ozsoy, A.S. (2017). Şizofrenide Dil Kullanımı: Basit Ve Karmaşık Tümce Yapısı Açısından İnceleme. In Neslihan Kansu Yetkiner \& Mehmet Şahin (Eds.), Dilbilim Çeviribilim Yazıları (pp. 114-128). Ankara: Anı Yayıncilik.

Potter, J. (1996). Representing reality: Discourse, rhetoric and social construction. London: Sage. https://doi.org/10.4135/9781446222119

Patel, K.R., Cherian, J., Gohil, K., \& Atkinson, D. (2014). Schizophrenia: overview and treatment options. Pharmacy and Therapeutics, 39 (9), 638.

Wicksell, R.K., Kihlgren, M., Melin, L., \& Eeg-Olofsson, O. (2004). Specific cognitive deficits are common in children with Duchenne muscular dystrophy. Developmental Medicine And Child Neurology, 46 (3), 154-159. https://doi. org/10.1111/j.1469-8749.2004.tb00466.x

\begin{abstract}
АННОТАЦИЯ
Цель. Первичными характерными особенностями шизофрении является нарушение мышления и речи. Соответственно, одной из диагностических характеристик шизофрении - это нарушение вербального общения. Целью настоящего исследования является анализ употребления номинальных и вербальных предикатов больными шизофренией и контрольной группы в их устной речи, поскольку эти предикаты требуют различной мыслительной обработки.
\end{abstract}

Материалы и методы. Исследование проводилось на материале речи 50-ти больных шизофренией, диагностированных в соответствии с критериями DSM-IV, и контрольной группы из 50-ти психиатрически здоровых испытуемых, соответствующих больным по возрасту, полу и уровню образования. Речь испытуемых оценивалась при помощи четырёх тестов: описание картинки, составление рассказа по картинкам, повествования на определенную заданную тему и свободное словесное повествование. Речь испытуемых, каждая из которой состояла из 8-10 минутных звукозаписей, была расширрована на основе дискурсивных символов Du Bois и проанализирована статистически и лингвистически.

Результаты. Результаты исследования показали, что количество номинальных и вербальных предикатов в речи больных шизофренией, отличалось от количества употребления в речи респондентов контрольной группы. Во всех тестах пациенты с шизофренией употребляли номинальные 
предикаты больше, чем респонденты контрольной группы. Испытуемые контрольной группы использовали значительно больще вербальных предикатов во всех mecmax.

Выводы. В данном исследовании была выдвинута гипотеза о том, что нарушение языка/речи больных шизофренией является центральным в этом заболевании и более важным, чем принято считать. Шизофреническая речь может рассматриваться как отражение основного нарушения - мышления. Исследование показало, что пациенты имели более упрощенную речь. Причиной этого упрощения является мыслительная обработка предикатов. Пациенты, как правило, чаще используют номинальные предикаты, так как для этого не требуется сложной мыслительной обработки, и, таким образом, они упрощают свою речь из-за своих языковых и мыслительных расстройств.

Ключевые слова: шизофрения, предикат, номинативное, вербальное, языковое расстройство, расстройство мышления.

\section{Озджан Вурал Айшегюль \& Куруоглу Гюльміра. Вживання номінальних $i$ вербальних предикатів у мові хворих на шизофренію}

\section{АНОТАЦІЯ}

Мета. Первинними характерними особливостями шизофренії $\epsilon$ порушення мислення і мовлення. Відповідно, однією з діагностувальних характеристик шизофренії $\epsilon$ порушення вербального спілкування. Метою цього дослідження $\epsilon$ аналіз вживання номінальних і вербальних предикатів хворими на шизофренію $і$ контрольної групи в їхньому усному мовленні, оскільки ці предикати вимагають різної розумової обробки.

Матеріали та методи. Дослідження проводилося на матеріалі мовлення 50-ти хворих на шизофренію, діагностованих відповідно до критеріїв DSM-IV, $i$ контрольної групи з 50-ти психіатрично здорових випробовуваних, які відповідні до хворих за віком, статтю та рівнем освіти. Мовлення випробовуваних оцінювалося за допомогою чотирьох тестів: опис картинки, складання розповіді за картинками, оповідання на запропоновану тему, оповідання на власну тему. Мовлення випробовуваних, кожне з якого складалося з 8-10 хвилинних звукозаписів, було розшифроване на основі дискурсивних символів Du Bois $i$ проаналізоване статистично й лінгвістично.

Результати. Результати дослідження показали, що кількість номінальних і вербальних предикатів у мовленні хворих на шизофренію відрізнялося від кількості вживання в мовленні респондентів контрольної групи. У всіх тестах пацієнти з шизофренією вживали номінальні предикати більше, ніж респонденті контрольна група. Досліджувані контрольної групи використовували значно більше вербальних предикатів у всіх тестах.

Висновки. В даному дослідженні була висунута гіпотеза про те, що порушення мови/мовлення хворих на шизофренію $є$ иентральним у цьому захворюванні i більш важливим, ніж прийнято вважати. Шизофренічне мовлення може 
розглядатися як відображення основного порушення - мислення. Дослідження показало, що пачієнти мали більш спрощене мовлення. Причиною цього спрощення є розумова обробка предикатів. Пацієнти, як правило, частіше використовують номінальні предикати, оскільки для цього не потрібно складної розумової обробки, i, таким чином, вони спрощують своє мовлення (висловлювання) через свої мовн й розумові розлади.

Ключові слова: шизофренія, предикат, номинативне, вербальне, мовний розлад, розлад мислення. 